\title{
Biochemical Resistance Mechanism Study of Jatropha curcas (Euphorbiaceae) Against Lasiodiplodia theobramae, a Leaf Blight and Necrosis Agent
}

\author{
Sama Hemayoro* \\ Laboratory of Biochemistry and Applied Chemistry (LABIOCA), University of Ouaga I Professor Joseph Ki-Zerbo, 03 BP 7021 Ouagadougou, \\ Burkina Faso \\ Sombié Pierre Alexandre Eric Djifaby \\ National Center of Scientific Research and Technology, Institute of Environment and Agricultural Research, Crop Production Department, 01 \\ P.O. Box 476 Ouagadougou, Burkina Faso \\ Laboratory of Biochemistry and Chemistry Applied (LABIOCA), University of Ouaga I Professor Joseph Ki-Zerbo, 03 BP 7021 Ouagadougou, \\ Burkina Faso \\ Hilou Adama \\ Laboratory of Biochemistry and Applied Chemistry (LABIOCA), University of Ouaga I Professor Joseph Ki-Zerbo, 03 BP 7021 Ouagadougou, \\ Burkina Faso
}

\section{Bonzi Schemaeza}

Rural Development Institute (IDR), University Nazi Boni (UNB), 01 BP 1091 Bobo-Dioulasso, Burkina Faso

\author{
Irénée Somda
}

Rural Development Institute (IDR), University Nazi Boni (UNB), 01 BP 1091 Bobo-Dioulasso, Burkina Faso

\begin{abstract}
This study was initiated in order to understand the biochemical mechanisms involved in the resistance of $J$. curcas to Lasiodiplodia theobromae. Artificial inoculations were done on young seedlings leaves of 8 J. curcas local accessions from Burkina Faso including 4 resistant and 4 susceptible. Two extractions were made for the evaluation of each biochemical parameter: one on the $1^{\text {st }}$ day before and the second on the $7^{\text {th }}$ day after inoculation. The study revealed that the response of $J$ curcas to L. threobromae infection is depending to the resistance or the susceptibility of accessions. It showed an increase in the content of biomolecules synthesis such as phenolic, flavonoids, proteins, photosynthetic pigments, salicylic acid and also an increase of catalase and trypsin inhibition activities. In susceptible accessions, the study revealed a decrease in the photosynthetic pigments and an increase in MDA content comparatively to resistant accessions. The ACP performed on the basis of the evaluated biochemical parameters showed that the axis F1 allows the separation of the resistant and the susceptible accessions, and indicated that the resistance of accessions result in the activation of biomolecules synthesis such as phenolic, flavonoids, proteins, photosynthetic pigments, salicylic acid and stimulation of catalase and trypsin inhibition activities. The F2 axis is associated with sugars content and, chymotrypsin inhibition and SOD activities. In susceptible accessions, an increase in MDA content and SOD activity were observed. This study represents an important step in combating leaf fungal diseases by opting to the green technology and by breeding for genotypes with inducing natural defense compounds.
\end{abstract}

Keywords: Jatropha; Resistance; Lasiodiplodia theobramae; Biochemical parameters.

(a) (1) CC BY: Creative Commons Attribution License 4.0

\section{Introduction}

Since the industrial revolution in the eighteenth century, both of world population and energy consumption have steadily increased. The consequences were a decrease in the availability of fossil fuels and an increase in the price of oil. With the continuing rise in global energy consumption, the energy crisis is having a deeper impact on global social and economic development [1]. In order to set up sustainable development programs and support research on renewable energies, liquid bioenergy production from vegetable oil is an ecological alternative that ensures the development [2]. Due to the need for energy alternatives, Jatropha curcas has attracted the attention of many researchers and investors and has become a popular culture in the world [3, 4].

$J$. curcas genotypes are known to have toxins like phorbol esters, curcins and trypsin inhibitor, which confer to the specie a resistance to many pests and various pathogens [5-7]. However, monoculture and the increase in cultivated areas have given rise to a number of phytosanitary problems in these recent decades [1], among which the most important are leaf diseases [5, 7]. In Burkina Faso, the major leaf diseases affecting J. curcas plantations are necrosis and leaf blight. Symptoms occur in Jatropha plants of all ages and are characterized by discolorations followed by necrosis or blighting from one point to spreading all the leaves. Over time, the disease can progress and cause death of the plants [7]. Many fungal pathogens have been identified as responsible of leaf blight and necrosis of J. curcas. Among them, Fusarium solani, Fusarium oxysporum, Curvularia lunata, Botrytis cinerae and 
Lasiodiplodia theobromae (Botyodiplodia theobromae) are the best known. Lasiodiplodia theobromae (Pat.) Griffon \& Maubl, a member of Botryosphaeriaceae family, has been recognized in Burkina Faso by many authors as an important pathogen with high aggressive potential on J. curcas [8].

Generally, the control of these diseases is dependent on the use of chemical pesticides, although concerns have been raised due to increasing costs, deterioration of soil quality and environmental risks, and also due to consumer preference of fruit free of residue $[9,10]$. Current scenarios to combat leaf fungal diseases are opting to the green technology by breeding for genotypes with induced natural defense compounds, thereby lowering both production costs and pesticide use $[9,11,12]$. Plants are known to respond to herbivory and microbial attacks through a range of factors, including those being of morphological, biochemical and molecular nature [9, 10]. Among biochemical factors, many previous studies in many species have confirmed involving of amino acids, total sugars, tannins, total phenols, protease inhibitors, and some osmotic and oxidant enzymes in resistance to fungal diseases [13, 14]. Thus, knowledge of resistance mechanisms may be important in selection and breeding for resistant genotypes [15]. Therefore, the aim of the present study was to evaluate some biochemical parameters of leaves in order to understand their possible associations to susceptibility or resistance of J. curcas to Lasiodiplodia theobromae, a leaf blight and necrosis agent.

\section{Materiel and Methods}

\subsection{Plant Materials}

The plant material is constituted of the seeds of eight (8) accessions of $J$. curcas from Burkina Faso including four (4) resistant and four (4) susceptible accessions. The seeds were used to set up a greenhouse nursery. The seeds were sown to a depth of $2 \mathrm{~cm}$ using pots with a 2-liters capacity. Each pot contains a mixture of sand, potting soil and organic manure in the proportions 3/1/1. This mixture, previously sterilized at $120^{\circ} \mathrm{C}$ for four (04) hours, allows good aeration of the roots and contains enough nutrients for the development of the plant. Pots were maintained in the greenhouse and were then watered every day.

\subsection{Pathogenicity Test}

Four weeks after sowing, five plants of each accession were inoculated with an isolate of L. threobromae previously produced. L. threobromae cultures were realized on Potato Dextrose Agar (PDA) medium during two weeks to produce inoculums. $20 \mathrm{ml}$ of sterile water were poured into each Petri dish (containing a culture of pure strain) to obtain the maximum conidia, and the surface of the colony is minutely brushed using a fine brush. The obtained spore suspension was filtered with muslin to separate the conidia from the mycelia fragments. The conidial suspension collected is added with two drops of $10 \%$ Tween 80 . Counts of conidia are then done under a Malassez counting cell microscope, and the concentration is adjusted to $2.10^{6}$ conidia. $\mathrm{ml}^{-1}$. The pathogenicity test was performed in the greenhouse according to the method described by Hernández-Cubero, et al. [6] after rubbing on the leaves of the carborandum, an abrasive powder which creates micro wounds on the leaves.

\subsection{Estimation of Resistance Parameters}

The leaves were collected the first day before inoculation and the $7^{\text {th }}$ days after inoculation for each accession to evaluate the resistance parameters.

\subsubsection{Determination of Photosynthetic pigments}

Photosynthetic pigments (Chlorophyll a and b) contents were determined in fresh leaves samples. $300 \mathrm{mg}$ of fresh leaves were homogenized in $1.5 \mathrm{ml}$ of $95 \%$ ethanol. The mixture is stirred and kept for 10 minutes in ice. After centrifugation for 1 minute at $20.000 \mathrm{~g}$, the absorbance of $300 \mu \mathrm{l}$ of the supernatant was measured at $665 \mathrm{~nm}$ for chlorophyll a and $649 \mathrm{~nm}$ for chlorophyll b according to method described by Mimouni, et al. [16]. The results are expressed as $\mu \mathrm{g} / 100 \mathrm{mg}$ of fresh leaves extracts $(\mu \mathrm{g} / 100 \mathrm{mg})$.

\subsubsection{Total Phenolic Content}

The total phenolic content of fresh leaves extracts was determined at $760 \mathrm{~nm}$ using gallic acid as reference compound, as described by Yasmina, et al. [17]. The total phenolics were expressed as $\mathrm{mg}$ of gallic acid equivalent per $100 \mathrm{mg}$ of fresh leaves weight (mg GAE/100 mg of fresh leaves).

\subsubsection{Flavonoid Content}

The total flavonoid content of the cowpea seed extracts was determined at $415 \mathrm{~nm}$ using the $\mathrm{AlCl}_{3}$ method described by Hilou, et al. [18]. The total flavonoid content was determined on a quercetin calibration curve and expressed as mg of quercetin equivalents (QE) per $100 \mathrm{mg}$ of fresh leaves weight (mg QE/100 mg of fresh leaves).

\subsubsection{Soluble Sugar Content}

$500 \mathrm{mg}$ of leaves were homogenized in $5 \mathrm{ml}$ of $80 \%$ hot ethanol. After cooling, the homogenate was centrifuged at $4000 \mathrm{rpm}$ for $10 \mathrm{~min}$. The supernatant was used to estimate the soluble sugar content of fresh leaves. The soluble sugar content was determined using the phenol-sulfuric acid method as described by DuBois, et al. [19] and the absorbance was red at $490 \mathrm{~nm}$. The total sugar content was expressed as $\mu \mathrm{g}$ glucose equivalent/100 gram of fresh leaves ( $\mu \mathrm{g} \mathrm{GE} / 100 \mathrm{~g}$ of fresh leaves). 


\subsubsection{Salicylic Acid Content}

$500 \mathrm{mg}$ of fresh leaves were homogenized in $5 \mathrm{ml}$ of distilled water and then centrifuged at $10000 \mathrm{~g}$ for 10 minutes. The salicylic acid content was determined in the supernatant according the method described by Yang, et al. [20] and expressed as $\mathrm{mg} / 100 \mathrm{mg}$ of fresh leaves (mg/100 $\mathrm{mg}$ of fresh leaves).

\subsection{Protein content and protease inhibition potential 2.4.1. Extraction of Protein}

Proteins were extracted according to the protocol described by Klomklao, et al. [21]. $500 \mathrm{mg}$ of leaves were homogenized in $5 \mathrm{ml}$ of $0.1 \mathrm{M} \mathrm{NaCl}$ for $5 \mathrm{~h}$ at $150 \mathrm{rpm} / \mathrm{min}$ at room temperature. The samples were centrifuged at $10000 \mathrm{~g}$ during $30 \mathrm{~min}$ and the supernatant were collected to determine the protein content and the protease inhibition potential of leaves.

\subsubsection{Protein Content}

Protein concentration was measured by Bradford method as described by Mimouni, et al. [16] using bovine serum albumin as a standard.

\subsubsection{Trypsin and Chymotrypsin Inhibition Assay}

Trypsin and chymotrypsin assay were determinate according a standard method described by Klomklao, et al. [21]. To measure trypsin inhibition (TI), $100 \mu \mathrm{l}$ of trypsin (from bovine pancreas, Sigma) at $0.0125 \mathrm{mg} \cdot \mathrm{ml}^{-1}$ and 100 $\mu \mathrm{l}$ of total protein extract were combined and were incubated for $5 \mathrm{~min}$ prior to the addition of $50 \mu \mathrm{l}$ of $N$ - $\alpha$-BenzoylDL-Arginine $p$-Nitroanilide (BAPNA) at $0.8 \mathrm{mg} \cdot \mathrm{ml}^{-1}$. The liberated $p$-nitroanilide was monitored for $25 \mathrm{~min}$ at 410 nm using a spectrometer.

To assay chymotrypsin inhibition potential (CI), $100 \mu 1$ of $\alpha$-Chymotrypsin (from bovine pancreas, Sigma) at $0.01875 \mathrm{mg} \cdot \mathrm{ml}^{-1}$ and $100 \mu \mathrm{l}$ of total protein extract were combined and were incubated for 5 min prior to the addition of $50 \mu \mathrm{l}$ of $N$-Glutaryl-L-Phenylalanine $p$-Nitroanilide (GPNA) at $3.2 \mathrm{mg}^{-\mathrm{ml}^{-1}}$. The liberated $p$-nitroanilide was monitored for $25 \mathrm{~min}$ at $410 \mathrm{~nm}$ using a spectrometer. Each reading was made against a control and trypsin and chymotrypsin inhibition activities of samples were estimated as percentages of inhibition according to the formula:

Percent inhibition $=\frac{\text { Vmax contr }- \text { Vmax sample }}{V \max \text { contr }} \times 100$

\subsection{Determination of antioxidant enzymes activities}

\subsubsection{Extraction of Antioxidant Enzymes}

$500 \mathrm{mg}$ of fresh leaves were milled using an extraction buffer containing $50 \mathrm{mM}$ sodium phosphate (pH 7.8). The superoxide dismutase and catalase activities were assayed on the supernatant obtained after centrifugation at $4000 \mathrm{rpm}$ for $10 \mathrm{~min}$ at $4^{\circ} \mathrm{C}$.

\subsubsection{Measurement of Superoxide Dismutase (SOD) Activity}

SOD was assayed using the standard method revealed by Ranjitha and Vijiyalakshmi [22]. This method is based on the inhibition of Epinephrine-Adrenochrome transition by the enzyme. The enzyme activity in the fresh leaves was determined using a spectrophotometer at $420 \mathrm{~nm}$. The enzyme activity was expressed in terms of unit min $\mathrm{mg}^{-1}$ ${ }^{1}$ protein.

\subsubsection{Measurement of Catalase (CAT) Activity}

CAT was assayed using standard protocol described by Ranjitha and Vijiyalakshmi [22]. The breakdown of $\mathrm{H}_{2} \mathrm{O}_{2}$ on addition of the enzyme is followed by absorbing the decrease in light absorption of peroxide solution in the UV region. The activity was measured as change in optical activity/density at $240 \mathrm{~nm}$ for $30 \mathrm{sec}$ interval during 3minutes. The CAT activity was expressed in terms of $\mu$ mole of $\mathrm{H}_{2} \mathrm{O}_{2}$ consumed/minute/mg protein.

\subsection{Lipid Peroxidation Assay}

The lipid peroxidation was estimated by the evaluation of Malondialdehyde (MDA) content according to the method described by Zineb, et al. [23]. The lipid peroxidation was expressed as concentration of MDA in fresh leaves $\left(\mu \mathrm{mol} . \mathrm{mg}^{-1}\right.$ of fresh leaves.

\subsection{Statistical Analysis}

The results are presented as mean \pm SD for triplicate analysis and were subjected to one-way analysis of ANOVA variation with Tukey's Significant Difference test and $\mathrm{P}<0.05$ was considered significant. The Pearson correlation test was used to study correlations between parameters and the effect of parameters variation on the susceptibility or the resistance of accessions. The statistical analysis was performed using XLSTAT Version Pro2017 and the graphs were drawn using Graph Pad Prism software version 5.0. 


\section{Results}

\subsection{Pathogenicity Test}

The results of the pathogenicity test are presented in Fig 1.

Fig-1. Leaf structures of some accessions of J. curcas at the 7th day after inoculation (the blue arrows indicate necrosis on inoculation zone)
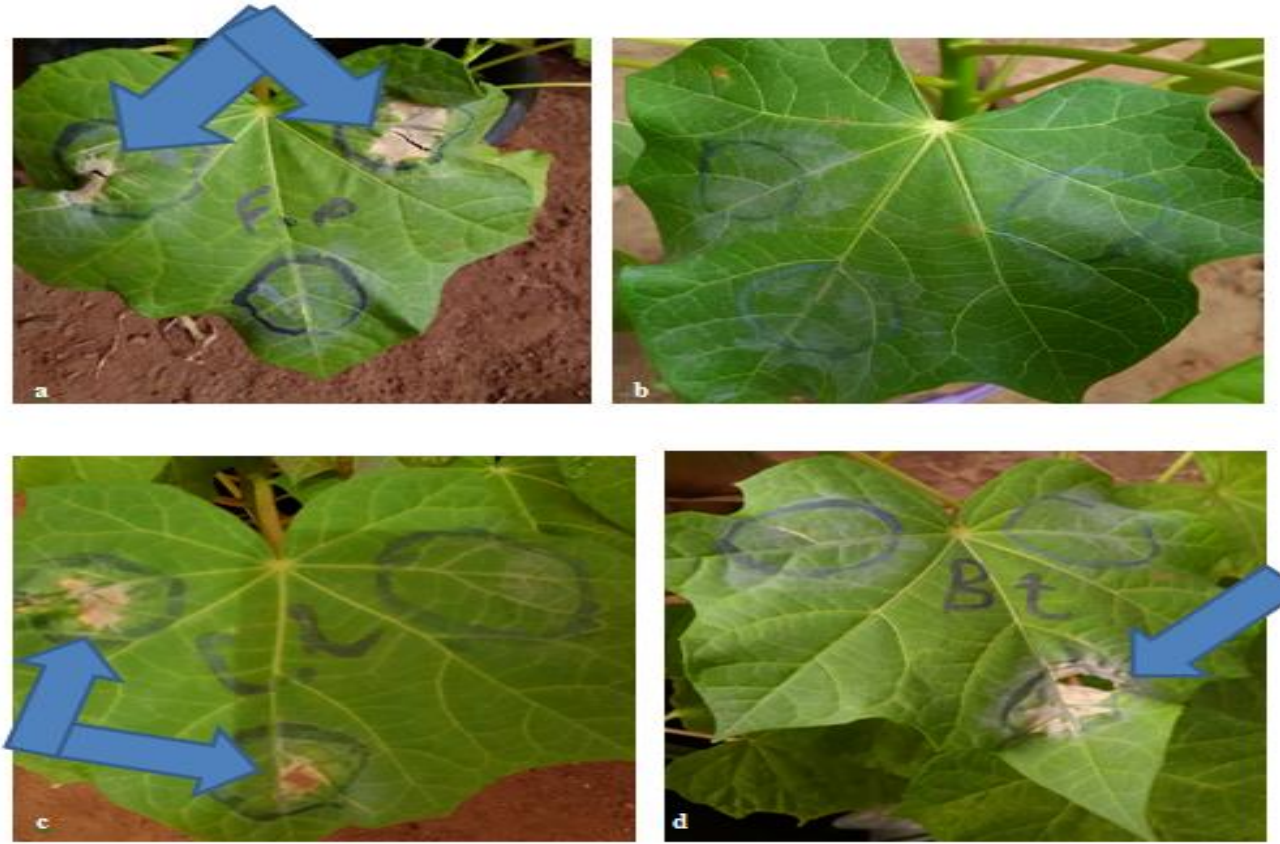

a: leaf of JR2 (resistant accession) at $7^{\text {th }}$ day; b: leaf of JS1(susceptible accession) at $7^{\text {th }}$ day; c: leaf of JS3 at (susceptible accession) $7^{\text {th }}$ day; $\mathbf{d}$ : leaf of JS4 (susceptible accession) at $7^{\text {th }}$ day

Inoculated plants showed different reactions to the fungal pathogen according to their susceptibility or their resistance/tolerance. Susceptible accessions presented necrosis on inoculation zones (Photo 1a) and resistant accessions did not show any symptoms of leaf diseases (Photo $1 \mathrm{~b}, 1 \mathrm{c}, 1 \mathrm{~d}$ ) at the $7^{\text {th }}$ day after inoculation.

\subsection{Chemical Compounds Contents}

The variation in the levels of various chemical compounds between the $1^{\text {st }}$ day before and the $7^{\text {th }}$ day after inoculation of different accessions of $J$. curcas are presented in Table 1.

Table-1. Variation of various chemical compounds contents of the 8 accessions

\begin{tabular}{l|l|l|l|l|l}
\hline Accessions & $\begin{array}{l}\text { Phenolic } \\
(\mathbf{m g ~ E A G / 1 0 0 m g})\end{array}$ & $\begin{array}{l}\text { Flavonoids } \\
(\mathbf{m g ~ E Q / 1 0 0 m g})\end{array}$ & $\begin{array}{l}\text { Proteins } \\
\left(\mathbf{1 0} \mathbf{-}^{\mathbf{2}} \mathbf{m g} / \mathbf{1 0 0} \mathbf{m g}\right)\end{array}$ & $\begin{array}{l}\text { Sugars } \\
(\boldsymbol{\mu g} \text { EG/100mg) }\end{array}$ & $\begin{array}{l}\text { Salicylic acid } \\
(\mathbf{m g} / \mathbf{1 0 0 m g})\end{array}$ \\
\hline JR1 & $8,098^{\mathrm{a}}$ & $8,651^{\mathrm{a}}$ & $11,228^{\mathrm{a}}$ & $64,679^{\mathrm{a}}$ & $13,667^{\mathrm{a}}$ \\
\hline JR2 & $8,166^{\mathrm{a}}$ & $8,151^{\mathrm{a}}$ & $11,489^{\mathrm{a}}$ & $33,616^{\mathrm{cd}}$ & $13,087^{\mathrm{a}}$ \\
\hline JR3 & $8,037^{\mathrm{a}}$ & $8,420^{\mathrm{a}}$ & $10,947^{\mathrm{a}}$ & $34,931^{\mathrm{bcd}}$ & $13,638^{\mathrm{a}}$ \\
\hline JR4 & $8,764^{\mathrm{a}}$ & $7,408^{\mathrm{a}}$ & $13,798^{\mathrm{a}}$ & $62,585^{\mathrm{ab}}$ & $13,667^{\mathrm{a}}$ \\
\hline JS1 & $1,207^{\mathrm{b}}$ & $0,564^{\mathrm{b}}$ & $1,082^{\mathrm{b}}$ & $27,218^{\mathrm{d}}$ & $5,333^{\mathrm{b}}$ \\
\hline JS2 & $1,746^{\mathrm{b}}$ & $0,974^{\mathrm{b}}$ & $-3,125^{\mathrm{b}}$ & $16,258^{\mathrm{d}}$ & $5,058^{\mathrm{b}}$ \\
\hline JS3 & $1,071^{\mathrm{b}}$ & $1,384^{\mathrm{b}}$ & $1,426^{\mathrm{b}}$ & $62,017^{\mathrm{abc}}$ & $4,826^{\mathrm{c}}$ \\
\hline JS4 & $1,339^{\mathrm{b}}$ & $1,625^{\mathrm{b}}$ & $0,568^{\mathrm{b}}$ & $43,020^{\mathrm{abcd}}$ & $5,348^{\mathrm{b}}$ \\
\hline
\end{tabular}

The contents of total phenolic, total flavonoid, protein and salicylic acid of the 8 accessions showed significant variation according to their resistance/susceptibility between $1^{\text {st }}$ day before and $7^{\text {th }}$ day after inoculation. The resistant accessions possessed the significant high content in these compounds comparatively to the susceptible accessions of $J$. curcas. The sugar content did not show any significant variation among the accessions according to their resistance/susceptibility. In fact, the resistant accessions JR1 and JR4 showed the high content of sugar but not significantly different with those of some susceptible accessions like JS3 and JS4.

\subsection{Photosynthetic Pigment Content}

The variation in the levels of photosynthetic pigments (chlorophyll a and b) at $1^{\text {st }}$ day before and $7^{\text {th }}$ day after inoculation are presented in the fig 2. 


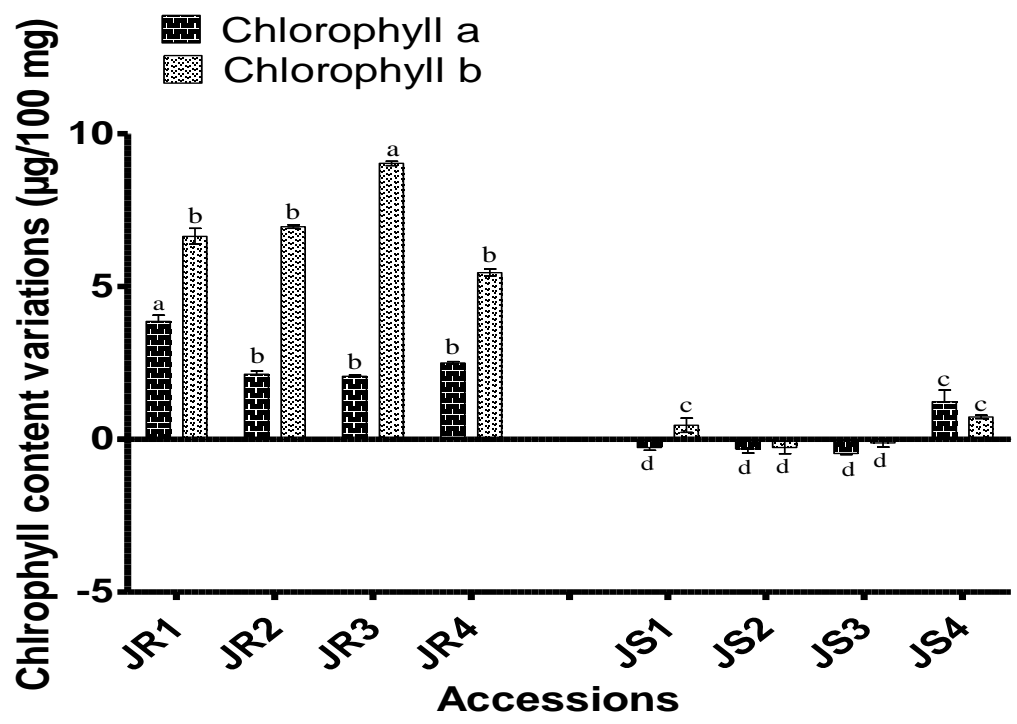

There is significant difference in the variation of photosynthetic pigments content according to the resistance or susceptibility of the accessions. Resistant accessions recorded significant increases in the two pigments between the $1^{\text {st }}$ day before and the $7^{\text {th }}$ day after inoculation, unlike the susceptible accessions recorded slight decreases in the two pigments content. The increases in the contents of the photosynthetic pigments are positively correlated with the resistance of the accessions.

\subsection{Proteases Inhibition Activities}

The variations in the percent inhibition of trypsin and chymotrypsin of the 8 accessions are shown in the fig 3 .

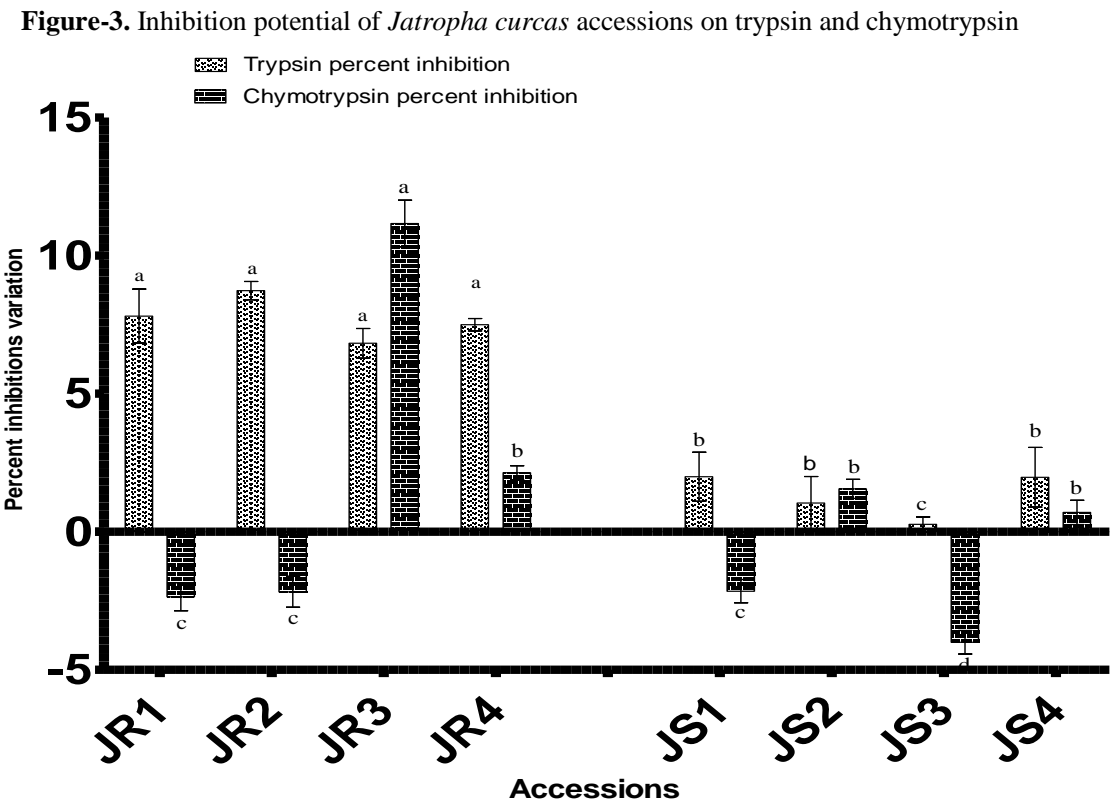

These results showed significant variation on the two proteases inhibition potential of the different accessions. The resistant accessions recorded a significant increase on the trypsin inhibition compared to the susceptible accessions which presented a decrease of trypsin inhibition activity in some accessions between $1^{\text {st }}$ day before and $7^{\text {th }}$ day after inoculation. The increase of trypsin inhibition percentage of the resistant accessions could be explained by the strong presence of trypsin inhibitors in resistant accessions comparatively to susceptible accessions of Jatropha curcas. The resistant accession JR3 showed the high increase of chymotrypsin inhibition activity among the 8 accessions. The resistant accession JR4 and the susceptible accessions JS2 and JS4 also showed increase in their chymotrypsin inhibition activity. In contrary, the resistant accessions JR1 and JR2, and the susceptible accessions JS1 and JS3 showed diminution in the chymotrypsin enzyme inhibition activity. The chymotrypsin inhibition potential of Jatropha curcas is not related to the resistance or the sensitivity of the accessions.

\subsection{Activities of Antioxidant Enzymes}

The antioxidant enzymes (catalase and SOD) activities variations of different accessions between $1^{\text {st }}$ day before and $7^{\text {th }}$ day after inoculation are presented in the fig 4 . 


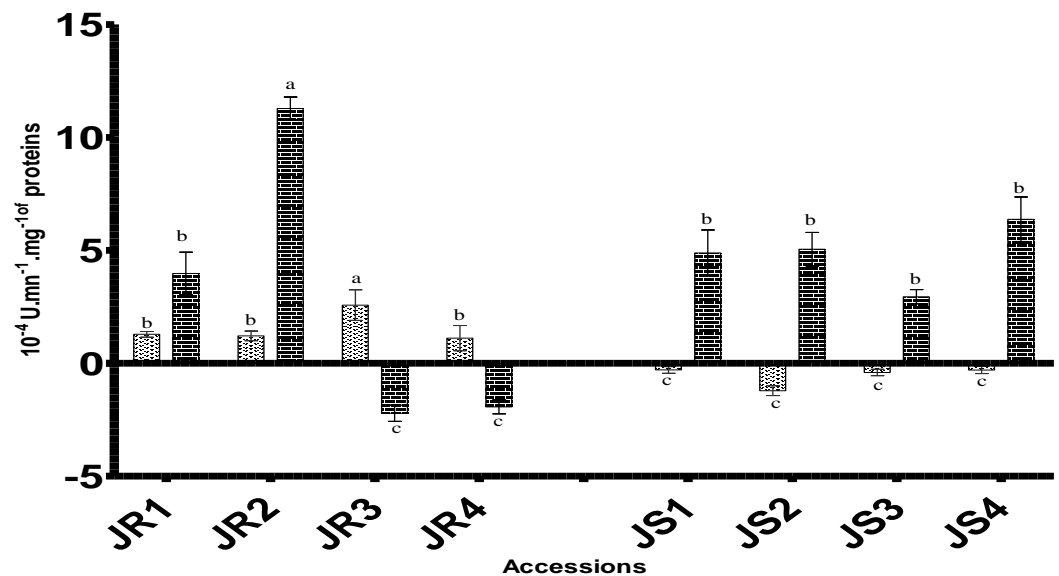

The results showed that the variation of the catalase enzyme activity is depending on the resistance or susceptibility of the accessions. The resistant accessions showed an increase in the activity of catalase while the activity of this enzyme decrease in the susceptible accessions between the first day before and the seventh day after inoculation. The JR2 resistant accession exhibited the high significant increase of superoxide dismutase activity among the accessions. The JR3 and JR4 resistant accessions showed a decrease of SOD activity between the $1^{\text {st }}$ day before and the $7^{\text {th }}$ day after inoculation. The significant increase of CAT enzyme activity after fungal infestation could explain their resistance mechanism.

\subsection{Lipid Peroxidation of Leaves}

The fig 5 shows the concentration of MDA expressed as $\mu \mathrm{mol} . \mathrm{mg}^{-1}$ of fresh leaves of the different accessions at 1 day before inoculation and 7 days after inoculation.

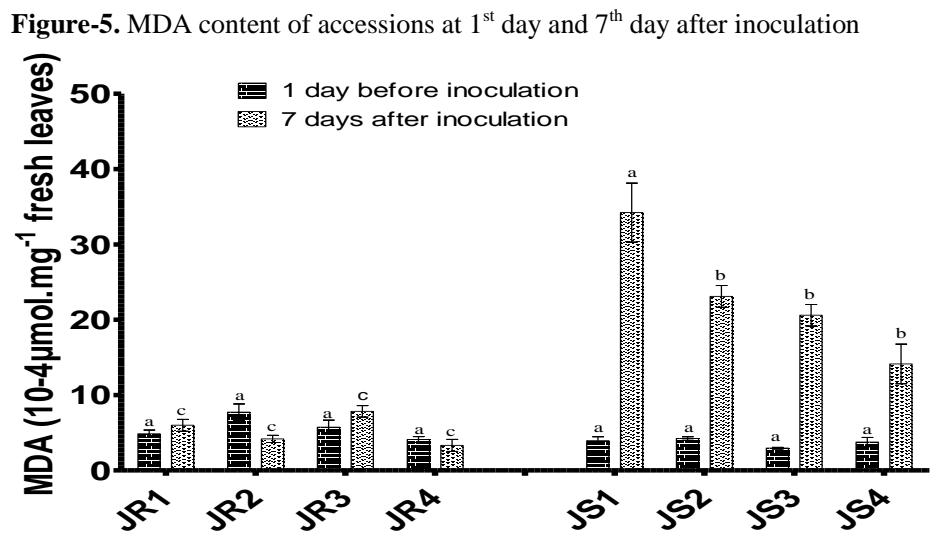

The results showed that at the $1^{\text {st }}$ day before inoculation, there is no significant difference between the MDA concentration in the leaves of both resistant and susceptible accessions. However, at $7^{\text {th }}$ day after inoculation, the susceptible accessions showed significant increases in MDA concentration than resistant accessions whose MDA concentration did not vary significantly. In addition, the susceptibility of accessions was significantly correlated with the increased of leaves MDA concentration.

\subsection{Correlations Between the Evaluated Parameters}

The table 2 shows the correlations between the different parameters evaluated.

Table-2. Pearson correlation coefficients between different chemical compounds

\begin{tabular}{|c|c|c|c|c|c|c|c|c|c|c|c|c|}
\hline Variables & Phenolic & Flavonoids & Proteins & Sugars & Salicylic acid & $\mathrm{ChA}$ & $\mathrm{ChB}$ & Trypsin & Chymotrypsin & Catalase & MDA & SOD \\
\hline Phenolic & 1 & & & & & & & & & & & \\
\hline Flavonoids & 0.983 & 1 & & & & & & & & & & \\
\hline Proteins & 0.963 & 0.953 & 1 & & & & & & & & & \\
\hline Sugars & 0.335 & 0.369 & 0.489 & 1 & & & & & & & & \\
\hline Salicylic acid & 0.992 & 0.993 & 0.965 & 0.338 & 1 & & & & & & & \\
\hline ChA & 0.874 & 0.901 & 0.856 & 0.492 & 0.868 & 1 & & & & & & \\
\hline $\mathrm{ChB}$ & 0.947 & 0.972 & 0.916 & 0.226 & 0.967 & \begin{tabular}{|l|l|}
0.834 \\
\end{tabular} & 1 & & & & & \\
\hline Trypsin & 0.974 & 0.966 & 0.949 & 0.276 & 0.974 & 0.892 & 0.935 & 1 & & & & \\
\hline Chymotrypsin & 0.362 & 0,355 & 0.268 & -0.266 & 0.341 & 0.207 & 0.502 & 0.260 & 1 & & & \\
\hline Catalase & 0.081 & 0.033 & -0.072 & 0.120 & 0.027 & 0.230 & -0.102 & 0.014 & -0.128 & 1 & & \\
\hline MDA & -0.884 & -0.903 & -0.848 & -0.411 & -0.866 & -0.856 & -0.835 & -0.866 & -0.298 & -0.003 & 1 & \\
\hline SOD & -0.262 & -0.220 & -0.294 & -0.351 & -0.233 & $-0,148$ & -0.258 & -0.082 & -0.620 & -0.138 & 0.092 & 1 \\
\hline
\end{tabular}

Values in bold indicate a significant value $(\mathrm{p}<0.5)$ 
Significant and positive relationship were found between variation in phenolic content and variation in flavonoids $(\mathrm{r}=0.983)$, total protein $(\mathrm{r}=0.963)$, salicylic acid $(\mathrm{r}=0.992)$, chlorophyll a $(\mathrm{r}=-0.856)$, chlorophyll $\mathrm{b}$ ( $\mathrm{r}$ $=0.947)$ and trypsin inhibition $(\mathrm{r}=0.974)$. High and significant correlations were also found with variation of flavonoids contents and protein $(\mathrm{r}=0.953)$, salicylic acid $(\mathrm{r}=0.993)$, chlorophyll a $(\mathrm{r}=0.901)$, chlorophyll b $(\mathrm{r}=$ $0.972)$ and trypsin inhibition $(\mathrm{r}=0.966)$. In addition, the variation in MDA content was negatively correlated with those of phenolic $(r=-0.884)$, flavonoids $(r=-0.903)$, total proteins $(r=-0.848)$, salicylic acid $(r=-0.866)$, and variation in trypsin inhibition $(r=-0.866)$. The variation of chymotrypsin inhibition was positively correlated with that of chlorophyll $b(r=0.502)$ and negatively correlated with the variation of SOD activity $(r=-0.620)$. The variation in total sugar content and catalase activity was not significantly correlated with any of the parameters evaluated.

\subsection{Comparative Analysis of the Variation of Resistant and Susceptible Accessions}

The principal component analysis was performed on the basis of variations in the different parameters evaluated between the $1^{\text {st }}$ day before inoculation and the $7^{\text {th }}$ day after inoculation. The table 3 shows coordinates of accessions. The results showed positive values for resistant accessions and negative values for susceptible accessions for F1 axis. This axis allows a separation of the resistant accessions of the susceptible accessions.

Table-3. Coordinates of the different accessions

\begin{tabular}{l|l|l|l|l|l|l|l|l}
\hline & JR1 & JR2 & JR3 & JR4 & JS1 & JS2 & JS3 & JS4 \\
\hline F1 & 2,967 & 2,339 & 2,890 & 2,860 & $-3,183$ & $-3,156$ & $-2,712$ & $-2,006$ \\
\hline F2 & $-1,694$ & $-1,170$ & 2,722 & 0,130 & 0,226 & 0,519 & $-0,581$ & $-0,152$ \\
\hline
\end{tabular}

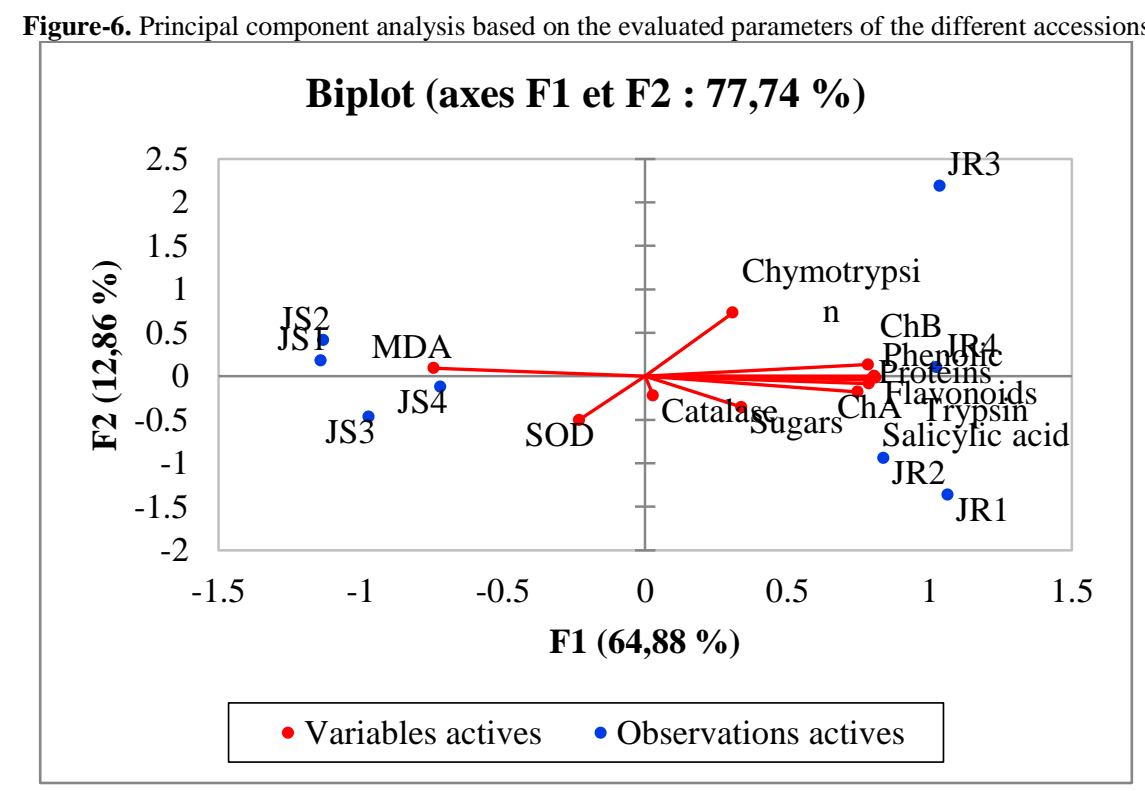

The fig 6 presents the repartition of the 8 accessions in the biplot (axis F1 and F2: $77.74 \%$ ). The contribution of the different variables for the F1 and F2 axes shows a strong contribution of the variables phenolic (12.500), total flavonoids (12.656), proteins (12.084), salicylic acid (12.478), chlorophyll a (10.776), chlorophyll b (11.850), MDA (10.636) and inhibition of trypsin activity (11.932) for F1 axis and sugars (12.212), chymotrypsin (51.795) and SOD (24.576) for the F2 axis $\left(12.86 \%^{\circ}\right)$.

\section{Discussion}

The study was initiated in order to identify the biochemical mechanisms involved in the resistance of $J$. curcas to L. threobromae, a fungal pathogen of this species. The results of the pathogenicity test showed necrosis or leaf blight on leaves of susceptible accessions while the leaves of resistant accessions did not show symptoms of leaf diseases. Similar results have been reported by Lanubile, et al. [24]. Lehmann, et al. [13] whom also recorded a variability of responses between susceptible and resistant accessions of maize inoculated with Fusarium proliferatum, Fusarium subglutinans, and Aspergillus flavus.

The resistant accessions showed a significant increase in the contents of polyphenols, flavonoids, proteins, salicylic acid and in photosynthetic pigments between the $1^{\text {st }}$ day before and the $7^{\text {th }}$ days after inoculation. The susceptible accessions did not show significant variations in the content of these compounds. The resistance of $J$. curcas to L. threobromae could be explain by the synthesis of these compounds in the resistant accessions. Similar results were reported in others studies. Indeed, Borković, et al. [25] reported that resistance to Monilinia fructicola in Prunus persica L. is associated with increased levels of polyphenols, flavonoids and various biomolecules. Vagiri, et al. [10] have also reported that phenolic compounds such as catechin and epicatechin are responsible for resistance to gray mold (Botrytis cinerea) in strawberries. According to Gharbi, et al. [26], Zraibi, et al. [27], the slight 
decrease in the photosynthetic pigments content in susceptible accessions could be explained by a degradation or a perturbation of the photosynthetic system. Also, Cameron, et al. [28]; Fu, et al. [29] have reported that resistance of plants is associated with increased accumulation of salicylic acid. Indeed, Klessig, et al. [30] reported that the transfer to $30^{\circ} \mathrm{C}$ of tobacco resistant cultivars to the mosaic virus block the accumulation of salicylic acid and lose the resistance character, the plant being unable to ensure the biosynthesis of the molecules of defense. Our results are also similar to those reported by Machado, et al. [31]; Zhu [32]. They reported that plant resistance to stress was associated with increased in protein levels. Machado, et al. [31], have reported that resistance to stress is associated with accumulation of certain proteins including proline. However, our results are contrary to those of Zhu [32]; Srinivasa, et al. [33] whom reported an increase in sugar levels in resistant accessions.

The variations in the levels of the biomolecules was accompanied by a significant increase in the inhibition activity of trypsin and in the activity of CAT in resistant accessions. Previous studies have reported similar results in other plant-pathogen ecosystems. Hegazi, et al. [15] reported plant resistance mechanisms involving antioxidant system enzymes including catalase (CAT) and proteases inhibition including trypsin inhibition. Lehmann, et al. [13] also reported that CAT activity were augmented after inoculation of fungi, especially in the resistant line of maize.

In susceptible accessions, an increase in MDA content was observed. Similar results were reported by Benhamou and Rey [34]; Zraibi, et al. [27]. They reported an increase in MDA content, an indicator of oxidative degradation of membrane lipids, in leaves of susceptible accessions. Srinivasa, et al. [33]; Benhamou and Rey [34] explained this result by perturbation of photosynthetic activity. Indeed, Gharbi [35] have reported that lipid degradation is due firstly to a disruption of thycoidal membranes, a loss of integrity of chloroplasts and hence a decrease in photosynthetic activity and secondly to a reduction of the activity of different enzymes of the antioxidant system of leaves. This would cause an accumulation of Reactive Oxygen Species or (ROS); such as superoxide ion $\mathrm{O}_{2}^{-}$, hydrogen peroxide $\mathrm{H}_{2} \mathrm{O}_{2}, \mathrm{OH}^{\cdot}$ Hydroxyl radical in the tissues and thus fortify the oxidation of membrane lipids. Thus, the reduction would promote the negative effects of lipid peroxidation reactions.

The ACP results indicate the involving in the resistance of accessions a multi-component defense system, in which regulation of chemical compound levels, trypsin inhibition photosynthetic pigments and catalase activity would play a central role in limiting the invasion and growth of pathogens. Similar results have been reported in various plant species. Indeed, according to $[14,34]$ the global expression of resistance to microbial pathogens is the result of a synergy of coordinated action in time and space between all whether direct or indirect defense mechanisms. Among the indirect mechanisms, there is parietal enhancement by incrustation of polysaccharide molecules, such as callose, phenylpropanoid pathway metabolites, such as lignin and phenolic compounds, and structural proteins and glycoproteins, such as hydroxyproline-rich glycoproteins (HRGPs). This parietal enhancement most often results in the formation of new barriers called papillae or parietal appositions which strongly contribute to delay the progression of the pathogen in the plant tissues and to prevent the diffusion of deleterious substances such as walls degrading enzymes, or toxins. Direct mechanisms include, among others, the synthesis of new proteins such as stress proteins, enzymes (antioxidant enzymes for example) and protease inhibitors $[15,34]$ as well as the production of phytoalexins, secondary metabolites with antimicrobial potential [14].

The positive and significant correlations between some of resistance parameters are very interesting results for breeding programs. Indeed, according to Freitas, et al. [36] knowledge of the magnitude of the correlation between characters is important in the choice of improvement methods and the formulation of strategies for the simultaneous selection for several desired characters. This research is an interesting study to determine sources influencing resistance to pathogens in Jatropha genotypes for consequent breeding purposes.

\section{Conclusion}

This study revealed that the response of $J$ curcas to L. threobromae infection is depending to the resistance or the susceptibility of accessions. It also revealed that the resistance of resistant accessions is the result of an activation of biomolecules synthesis such as phenolic, flavonoids, proteins, photosynthetic pigments, salicylic acid and increase of catalase activity and trypsin inhibition activity which would aim at either curbing the penetration of the pathogen or destroying it.

In susceptible accessions, pathogens would attack by degrading or disrupting photosynthetic activity and increasing peroxidation of membrane lipids. These results open voices for improvement $J$. curcas resistance in breeding programs and in the identification of $J$. curcas natural defense stimulators, which could lead to effective management of its phytosanitary problems by non-recourse chemical pesticides.

\section{Acknowledgements}

This work was supported by the WARC Travel Grant. We thank sincerely West African Research Association (WARA) for its support in realizing of this work.

\section{References}

[1] Uc-Várguez, A., López-Puc, G., Góngora-Canul, C. C., Martinez- Sebastián, G., and Aguilera-Cauich, E. A., 2017. "Spatio-temporal spread of foot rot (lasiodiplodia theobromae) in jatropha curcas 1. Plantations in yucatan, Mexico." European Journal of Plant Pathology, vol. 150, pp. 991-1000.

[2] Kumar, R. and Das, N., 2018. "Survey and selection of jatropha curcas 1. Germplasm: Assessment of genetic variability and divergence studies on the seed traits and oil content." Industrial Crops and Products, vol. 118, pp. 125-130. 
[3] Ahmed, I. A., Munif, Y. A., and Mutaqin, K. H., 2017. "Exploring endophytic bacteria origin from jatropha curcas 1. And their potential to enhance plant growth in eggplant." Pak J Biotechnol, vol. 14, pp. 238 - 244. N., F. D. M., Saragih, T. H., Hamdianah, A., Mahmudy, W. F., and Anggodo, Y. P., 2017. "Optimized fuzzy neural network for jatropha curcas plant pisease identification." In International Conference on Sustainable Information Engineering and Technology (SIET).

[5] Djenda, Y., Nacro, S., Wonni, I., Ouédraogo, I., and Ouédraogo, L., 2016. "Fungal agents associated with jatropha curcas 1. Seeds from burkina faso." Academy of Agriculture Journal, vol. 1, pp. 61 - 64.

[6] Hernández-Cubero, L. C., Ampofo, P., Montes, J. M., and Voegele, R. T., 2017. "Identification of pathogenic fungi and preliminary screening for resistance in jatropha curcas 1. Germplasm." European Journal of Plant Pathology, vol. 149, pp. 325-336.

[7] Machado, A. R. and Pereira, O. L., 2013. "Major diseases of the biofuel plant, physic nut , jatropha curcas." World's largest Science,Technology \& Medicine,

[8] Ji, C., Chen, C., Wang, X., Liu, Y., Liu, J., and Zeng, B., 2017. "A report on canker disease of falcataria moluccana caused by lasiodiplodia theobromae in China." Crop Protection, vol. 91, pp. 89-92.

[9] Meena, Nayantara, and Saharan, a., 2017. "Effective biocontrol of leaf rot disease on aloe vera plant by pgpr in green house experiment." Bulletin of Environment, Pharmacology and Life Sciences, vol. 7, pp. 2428.

[10] Vagiri, M., Eva, J., and Kimmo, R., 2017. "Phenolic compounds in black currant leaves - an interaction between the plant and foliar diseases." Journal Of Plant Interactions, vol. 12, p. 12.

[11] Dhillon, M. K. and Chaudhary, D., 2018. "Physicochemical mechanisms of resistance in sorghum to chilo partellus, Swinhoe." Indian Journal of Experimental Biology, vol. 56, pp. 29-38.

[12] Terna, T. P. and Simon, A., 2017. "Biological control of some fungal pathogens of tomato (solanum lycopersicum mill.) using ethanolic leaf extracts of plants." Journal of Environmental and Agricultural Sciences vol. 13, pp. 9-15.

[13] Lehmann, S., Serrano, M., L’Haridon, F., Tjamos, S. E., and Metraux, J.-P., 2015. "Reactive oxygen species and plant resistance to fungal pathogens." vol. 112, pp. 54-62.

[14] War, A. R., Paulraj, M. G., Ahmad, T., Buhroo, A. A., Hussain, B., Ignacimuthu, S., and Sharma, H. C., 2014. "Mechanisms of plant defense against insect herbivores." Plant Signaling \& Behavior, vol. 7, pp. 1306-1320.

[15] Hegazi, A. M., Ama, 1. M. E.-S., and Ghoname, A. A., 2017. "Mitigation of salt stress negative effects on sweet pepper using arbuscular mycorrhizal fungi (amf), bacillus megaterium and brassinosteroids (brs)." Gesunde Pflanzen vol. 69, pp. 91-102.

[16] Mimouni, H., Wasti, S., Manaa, A., Gharbi, E., Chalh, A., Vandoorne, B., Lutts, S., and Ahmed, H. B., 2016. "Does salicylic acid (sa) improve tolerance to salt stress in plants? A study of sa effects on tomato plant growth, water dynamics, photosynthesis, and biochemical parameters. Omics." A Journal of Integrative Biology, vol. 20, pp. 180-190.

[17] Yasmina, L., Rihab, H., and Meriem, K., 2016. "Etude de la peroxydation lipidique chez une plante médicinale haloxylon scoparium pomel." Journal of Bioresources Valorization, vol. 1, pp. 28-33.

[18] Hilou, A., Bougma, A., and Dicko, M. H., 2017. "Phytochemistry and agro-industrial potential of native oilseeds fromwest africa, African grape ,lannea microcarpa, Marula ,sclerocarya birrea, and butter tree, pentadesma butyracea." Agriculture, vol. 7, pp. 1-11.

[19] DuBois, M., Gilles, K., Hamilton, J., Rebers, P., and Smith, F., 1956. "Colorimetric methodfor determination of sugars and related substances." Analytical Chemistry, vol. 28, pp. 350-356.

[20] Yang, T., Zhu, L.-s., Meng, Y., Lv, R., Zhou, Z., Zhu, L., Lin, H.-h., and Xi, D.-h., 2018. "Alphamomorcharin enhances tobacco mosaic virus resistance in tobacco nn by manipulating jasmonic acidsalicylic acid crosstalk." Journal of Plant Physiology, vol. 223, pp. 116-126.

[21] Klomklao, S., Benjakul, S., Kishimura, H., Osako, K., and Tanaka, M., 2009. "A heat-stable trypsin inhibitor in adzuki bean vigna angularis, Effect of extraction media, purification and biochemical characteristics." International Journal of Food Science \& Technology, vol. 45, pp. 163-169.

[22] Ranjitha, J. S. and Vijiyalakshmi, M. A., 2013. "Bhagiyalakshmi am, Biological assay of in vitro antioxidant and antibacterial activity of the whole plant material cleome gynandra linn." Research Journal of Pharmaceutical, Biological and Chemical Sciences, vol. 4, pp. 97-102.

[23] Zineb, M., Fabienne, D., Laurence, M., Rémi, L., and Moulay, B., 2015. "Study of lipid peroxidation (mda) and antioxidative activity (pod) in two halophyte, Atriplex halimus 1. And atriplex canescens (pursh) nutt under salt effect." International Journal of Innovation and Applied Studies, vol. 10, pp. 450-458.

[24] Lanubile, A., Maschietto, V., De, L. S., Battilani, P., Paciolla, C., and Marocco, A., 2015. "Defense responses to mycotoxin-producing fungifusarium proliferatum, f. Subglutinans, andaspergillus flavusin kernels of susceptible and resistant maize genotypes." Molecular Plant-Microbe Interactions, vol. 28, pp. 546-557.

[25] Borković, B., Malenčić, Đ., Prvulović, D., Kiprovski, B., Stojšin, V., and Iličić, R., 2017. "Screening for polyphenol compounds and antioxidant capacity of sweet cherry fruits infected with monilinia laxa." Contemporary Agriculture, vol. 66,

[26] Gharbi, Y., Barkallah, M., Bouazizi, E., Hibar, K., Gdoura, R., and Triki, M. A., 2017. "Lignification, phenols accumulation, induction of pr proteins and antioxidant-related enzymes are key factors in the resistance of olea europaea to verticillium wilt of olive." Acta Physiol Plant, vol. 39, pp. 1-15. 
[27] Zraibi, L., Nabloussi, A., Merimi, J., El, A. A., and Kajeiou, M., A. K., 2012. "H eSC Effet du stress salin sur des paramètres physiologiques et agronomiques de différentes variétés de carthame, Carthamus tinctorius 1." Al Awamia, pp. 25-126.

[28] Cameron, R. K., Paiva, N. L., Lamb, C. J., and Dixon, R. A., 1999. "Accumulation of salicylic acid and pr1 gene transcripts in relation to the systemic acquired resistance (sar) response induced by pseudomonas syringae pv. Tomato in arabidopsis." Physiological and Molecular Plant Pathology, vol. 55, pp. 121-130.

[29] Fu, J., Liu, H., Li, Y., Yu, H., Li, X., Xiao, J., and Wang, S., 2010. "Manipulating broad-spectrum disease resistance by suppressing pathogen-induced auxin accumulation in rice." Plant Physiology, vol. 155, pp. 589-602.

[30] Klessig, D. F., Choi, H. W., and Dempsey, D. M. A., 2018. "Systemic acquired resistance and salicylic acid, Past, present, and future." Molecular Plant-Microbe Interactions, vol. 31, pp. 871-888.

[31] Machado, R. A. R., Arce, C. C. M., Ferrieri, A. P., Baldwin, I. T., and Erb, M., 2015. "Jasmonatedependent depletion of soluble sugars compromises plant resistance tomanduca sexta." New Phytologist, vol. 207, pp. 91-105.

[32] Zhu, J.-K., 2016. "Abiotic stress signaling and responses in plants." Cell, vol. 167, pp. 313-324.

[33] Srinivasa, G. R., Nageswara, N. R. R., and Surekha, C., 2015. "Induction of plant systemic resistance in legumes cajanus cajan, vigna radiata, vigna mungo against plant pathogens fusarium oxysporum and alternaria alternata - a trichoderma viride mediated reprogramming of plant defense mechanism." International Journal of Recent Scientific Research, vol. 6, pp. 4270-4280.

[34] Benhamou, N. and Rey, P., 2012. "Stimulateurs des défenses naturelles des plantes, Une nouvelle stratégie phytosanitaire dans un contexte d'écoproduction durable." Phytoprotection, vol. 92, p. 1.

[35] Zraibi, L., Nabloussi A, Merimi J., El Amrani A., Kajeiou M., A., K., and H, e. S. C., 2012. "Effet du stress salin sur des paramètres physiologiques et agronomiques de différentes variétés de carthame (Carthamus tinctorius L.)." Al Awamia, pp. 25-126.

[36] Freitas, R. G., Missio, R., Matos, F., Resende, M. D. V., and Dias, L. A. S., 2011. "Genetic evaluation of jatropha curcas 1, An important oilseed for biodiesel production." Genetic and Molecular Research, vol. 3, pp. 1490-1498. 